\title{
Association Between ACE I/D Gene Polymorphism and Hypertension in Smokers
}

Hateem Zafar Kayani, Sana Riaz, Nageen Hussain

Department of Microbiology and Molecular Genetics, Quaid-e-Azam Campus, University of the Punjab,

Number of figures: 03

Number of tables: 06

Corresponding author

Lahore, Pakistan.

\author{
Hateem Zafar Kayani
}

Email: hareemhh@ymail.com

Phone number: 0321-5837132

\section{Abstract}

The main aim is to study the association of ACE I/D polymorphism with healthy smokers. A total of 49 smokers and 49 healthy controls were enrolled in this study. Intron 16 of the ACE gene was amplified by using nested PCR. The possible banding patterns were as follows; DD, 210 bp fragments; II, 264bp and 498 bp fragments; ID, 210 bp, 264 bp, and 498 bp fragments. The subjects comprised of males only. Among 49 subjects the frequency of ACE DD genotype was $75.5 \%$ (37/49), II 24.5\% (12/49), while no ID genotype was found in the study. All controls showed DD genotype. The association of ACE I/D polymorphism with different levels of blood pressure were found to be significant.

Keywords: Angiotensin converting enzyme; Polymerase chain reaction; Genotype; Polymorphism.

\section{Council for Innovative Research}

Peer Review Research Publishing System

\section{Journal: JOURNAL OF ADVANCES IN BIOTECHNOLOGY}

Vol. 4, No. 1.

www.cirjbt.org , jbteditor@gmail.com 


\section{INTRODUCTION:}

Angiotensin converting enzyme (ACE) gene I/D polymorphism has been reported but the results are still controversial and such association has not yet been established conclusively. Hypertension or high blood pressure is a chief risk factor for different diseases like stroke; myocardial infarction also called heart attacks, heart failure, aneurysms of the arteries and peripheral arterial disease and is a cause of chronic kidney disease. Even slightly raised blood pressure in arteries causes reduction in life expectancy. Balanced diet and changes in lifestyle can improve blood pressure control. In result, risk of related health complications is reduced. Hypertension is classified as either primary or essential hypertension or secondary hypertension. Approximately 90 to $95 \%$ of cases are categorized as primary hypertension with no basic medical cause. Remaining 5 to $10 \%$ of cases are of secondary hypertension. It is caused by other factors that affect the kidneys, arteries, heart or endocrine systems [1].

ACE gene is directly involved in Renin Angiotensin Aldosterone System (RAAS), Kinin Kallikrein System. It has a significant role in degradation of amyloid beta peptide and signal transduction GPlase activity, in vivo. The location of ACE gene is on the short arm of chromosome 17 at position 23(17q23) in humans. It is expressed in a variety of tissues which include lung, vascular endothelium, kidney, heart and testes. Basically, it is responsible for the conversion of Angiotensin I to Angiotensin II and degrades bradykinin due to its metalloproteinase enzymatic activity. The ACE I/D polymorphism in intron 16 of ACE gene have been associated to the amount of circulating enzyme. The homozygous individuals for the deletion (DD) have about two fold increased level of circulating enzyme as compare to those who are homozygous for the insertion (II). Angiotensin II is important to increase vascular smooth muscle cell proliferation, monocyte adhesion, platelet adhesion and aggregation. The genotype of ACE or plasma ACE concentrations has been concerned in the etiology of the disease [2]. In mammals, ACE has a main role in homeostatic mechanism as it is responsible for the maintenance of normal blood pressure and electrolyte balance in the body. Basically, angiotensins are peptides and these act as vasoconstriction agents which increases the blood pressure. ACE I or kininase II , is a dipeptidylcarboxypeptidase which plays a significant role in the regulation of blood pressure electrolyte balance by converting angiotensin I into angiotensin II. Angiotensin II is a potent vasopressor and stimulates secretion of aldosterone. It also inactivates bradykinin which is a potent vasodilator. There are two isozymes encoded by ACE gene. Somatic ACE isozyme and testicular (germinal) ACE isozyme, expressed in a variety of tissues, as vascular endothelial cells, renal epithelial cells, and testicular Leydig cells, while germinal ACE isozyme is expressed in sperms only. ACE is present in the membrane bound form on the surface of vascular endothelial cells, also circulates in plasma. Basically, plasma enzyme is synthesized in vascular endothelium. While in normal persons, levels of plasma ACE can show as much as a 5 times interindividual variation, but in case of intraindividual variation is small [3]. The main objective of this research is to study the association of ACE I/D polymorphism in healthy smokers.

\section{MATERIALS AND METHODS:}

Blood samples from 49 subjects were collected in EDTA coated vacutainers and written informed consent form was received from each subject. Genomic DNA was extracted from all blood samples by using kit method (Fermentas, USA). The ACE I/D polymorphisms were assayed by using nested PCR. It is a triple primer method with a nested PCR primer situated within the insertion sequence of I allele. The involvement of a third internal PCR primer removed the chances of non-specific amplification. The reaction mixture (50 $\mu /$ reaction) contained $25 \mu$ l of the $2 X$ PCR mix, template DNA 2.0 $\mu$, triple primer mixture $1.0 \mu \mathrm{l}$ and distilled water in quantity of $22 \mu \mathrm{l}$. To amplify this region of ACE, simple PCR program was used for 35 cycles using 96 wells thermal cycler. The annealing temperature was optimized by varying the temperature from $62^{\circ} \mathrm{C}$ to $50^{\circ} \mathrm{C}$. Later on, the PCR product was detected by using $1 \%$ agarose gel and DNA ladder (Fermentas, USA) was used to detect the banding pattern. The possible genotypes were having a banding pattern as follows; DD, $210 \mathrm{bp}$ fragments; II, 264bp and 498 bp fragments; ID, 210 bp, 264 bp, and 498 bp fragments. Univariate analysis and chi square test were also applied.

\section{RESULTS:}

The subjects comprised of males only because the prevalence of smoking is rare in females. Mean age of subjects was $41 \pm 21$ (20-70 years) (fig. 1). No significant association was observed between the age groups and ACE I/D polymorphism (table 1). Moreover, the study focused on regions of Lahore and Rawalpindi in Punjab, Pakistan. In this study, among 49 subjects the frequency of ACE DD genotype was found to be $75.5 \%(37 / 49)$, II $24.5 \%$ (12/49), while PCR products did not confirm the presence of ID type of polymorphism (fig. 2, fig. 3). All controls showed DD genotype. The association of ACE I/D polymorphism with different levels of blood pressure were found to be significant $(p<0.05)$ (table 2$)$. The association of ACE I/D polymorphism with smokers and controls were found to be significant $(p<0.05)$ (table 3 ) and between ACE I/D polymorphism and affection status of hypertension (table 5 . The association was not found to be significant in case of Body Mass Index (BMI) and types of smoking (table 4). No significant association was observed between smokers and ACE I/D polymorphism (table 6). 


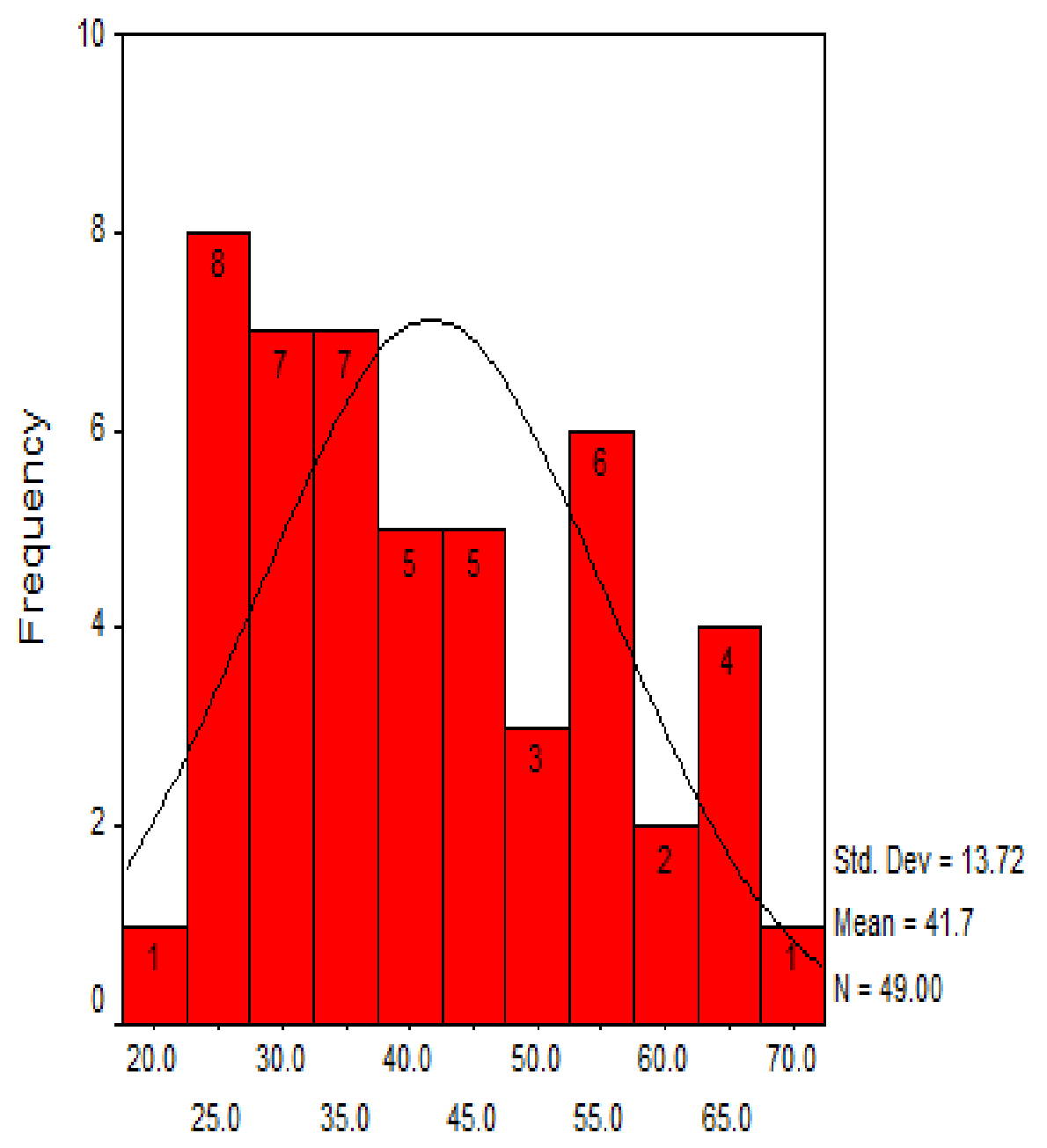

\section{Age (years)}

Fig 1: Distribution of Smoker $(n=49)$ according to the age 


\section{ISSN 2348-6201}

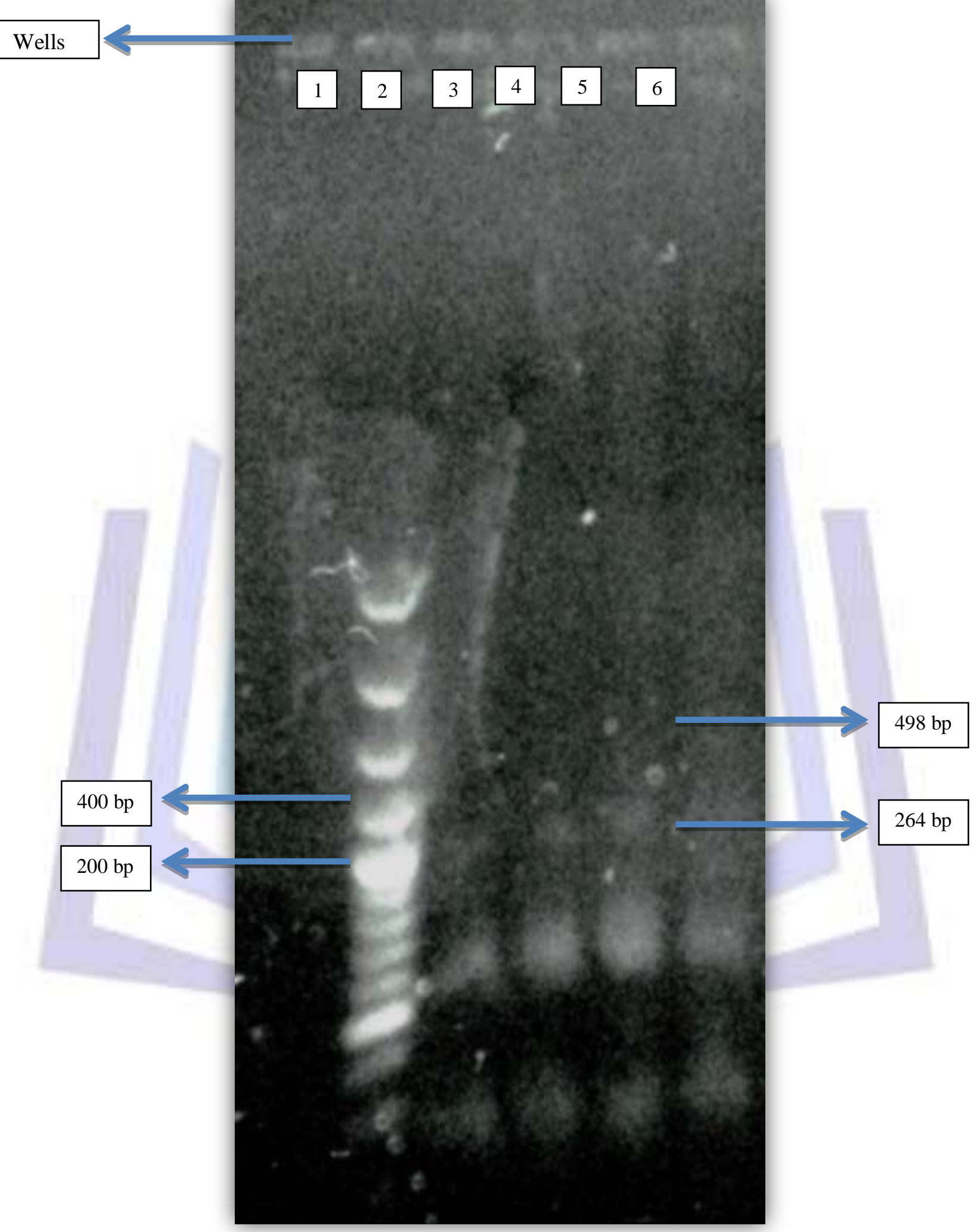

Figure 2: Gel containing labeled PCR amplified DNA samples along with DNA ladder 
Table 1. Correlation between ACE I/D Polymorphism and Age Group

\begin{tabular}{|c|c|c|c|}
\hline \multirow{2}{*}{ Age groups (years) } & \multicolumn{2}{|c|}{ Type of polymorphism } & P value \\
\hline $20-40(n=24)$ & DD $(n=37)$ & II (n=12) & 0.472 \\
\hline $41-60(n=18)$ & 19 & 04 & \\
\hline$>60(n=07)$ & 14 & 04 & 03 \\
\hline
\end{tabular}

Table 2. Correlation of ACE I/D Polymorphism With Different Levels of Blood Pressure

\begin{tabular}{|c|c|c|c|c|}
\hline \multirow{2}{*}{ Type of polymorphism } & \multicolumn{3}{|c|}{ State of Hypertension } & P value \\
\hline & Hypertensive & Normotensive & Pre-hypertensive & \\
\hline DD $(n=37)$ & 06 & 23 & 08 & 0.036 \\
\hline II $(n=12)$ & 06 & 03 & 03 & \\
\hline
\end{tabular}

Table 3. Association of ACE I/D Polymorphism With Smokers and Controls

\begin{tabular}{|c|c|c|c|}
\hline Type of polymorphism & Smokers & Controls & P value \\
\hline II $(n=12)$ & 12 & 00 & 0.0001 \\
\hline DD $(n=86)$ & 37 & 49 & \\
\hline
\end{tabular}


Table 4. Association of Body Mass Index (BMI) and Smoking

\begin{tabular}{|l|c|c|c|c|}
\hline Types of smokers & \multicolumn{2}{|c|}{ Body Mass Index (BMI) } & P value \\
\hline & Underweight & Normal weight & Overweight \\
\hline $\begin{array}{l}\text { Chain (more than 5cig/day) } \\
(n=22)\end{array}$ & 02 & 07 & 13 & 0.607 \\
\hline $\begin{array}{l}\text { Steady (3cig/day) } \\
(n=17)\end{array}$ & 00 & 07 & 10 & 07 \\
\hline $\begin{array}{l}\text { Rare (1cig/day) } \\
(n=10)\end{array}$ & 01 & 02 & & \\
\hline
\end{tabular}

Table 5. ACE I/D Polymorphism and Affection Status of Hypertension

\begin{tabular}{|c|c|c|c|c|}
\hline \multirow{2}{*}{ Type of polymorphism } & \multicolumn{3}{|c|}{ Affection status of Hypertension } & Pre-hypertensive \\
\hline & Hypertensive & Normotensive & value \\
\hline DD $(n=37)$ & 05 & 25 & 07 & 0.0007 \\
\hline II $(n=12)$ & 07 & 01 & 04 & \\
\hline
\end{tabular}

Table 6. Association of Smokers and ACE I/D Polymorphism

\begin{tabular}{|c|c|c|c|}
\hline Type of smokers & \multicolumn{2}{|c|}{ Type of polymorphism } & P value \\
\hline & DD & II & \\
\hline Chain (5 cig/day) $(n=22)$ & 18 & 04 & 0.688 \\
\hline $\begin{array}{l}\text { Steady }(3 \mathrm{cig} / \text { day }) \\
(n=17)\end{array}$ & 14 & 03 & \\
\hline Rare (1cig/day) $(n=10)$ & 07 & 03 & \\
\hline
\end{tabular}




\section{DISCUSSION:}

The etiology of primary hypertension is unknown however its diverse hemodynamic and pathophysiologic derangements are unlikely to result from a single cause. Heredity is one of the main predisposing factors, but the exact mechanism is unclear [4]. It is observed that environmental factors only influence the instances of hypertension in those patients who are genetically susceptible [5]. Association of ACE D allele with hypertension in African Americans, Chinese and Japanese population has already been established [6-7]. In Pakistani population, I allele was found to be associated with hypertension [8]. In the present study, among 49 smokers, the frequency of ACE DD genotype was found to be $75.52 \%$ (37/49), II 24.48\% (12/49) and a significance difference was observed between the ACE gene I/D polymorphism and different levels of blood pressure.

The variations in the association of ACE I/D polymorphism with essential hypertension may be either due to varied ethnicity [9] or the various other genetic and environmental factors implicated in the regulation of blood pressure [10]. Another study carried out in the Bangladeshi population found a significant association of ACE I/D polymorphism with hypertension [11]. In India, the ACE I/D polymorphism study was carried out on two geographical opposite populations (Punjabi and Southern) and a positive association was observed [12, 13]. Pakistan has a relatively homogenous population as cousin marriages are very common so genomic structure must be unique. Thus there is a need to study ACE I/D polymorphism in healthy smokers according to the cast.

\section{REFERENCES:}

[1] Barley, J., Blackwood, A., Carter, N.D., Crews, D.E., Cruickshank, J.K., Jeffery, S., Ogunlesi, A.O., 1994. Angiotensin converting enzyme insertion/deletion polymorphism: association with ethnic origin. J Hypertens. 12(8):955-957.

[2] Bhavani, B.A., Padma, T., Sastry. B.K.S., Krishna, R.N., Nausheen, K., 2005. The Insertion I/ Deletion D polymorphism of Angiotensin Converting Enzyme (ACE) Gene Increase the Susceptibility to Hypertension and / or Diabetes. Int $J$ Hum Genet., 5: 247-252.

[3] Guyton, A.C., Hall, J.E., Lohmeier, T.E., Jackson, T.E., Kastner, P.R., 1981. Blood pressure regulation: basic concepts. Fed Proc., 40(8):2252-2256.

[4] Harrap, S., 1994. Hypertension: genes versus environment. The lancet., 344(8916):p.169-171.

[5] Humphries, S.E., L. Morgan., 2004. Genetic risk factors for stroke: insights into pathophysiology from candidate gene approaches. Elsevier., 14:23-30.

[6] Ismail, M., Akhtar, N., Nasir, M., Firasat, S., Ayub, Q., Khaliq, S., 2004. Association between the angiotensin converting enzyme gene insertion/deletion polymorphism and essential hypertension in young Pakistani patients. J Biochem Mol Biol., 37(5):552-555.

[7] Morise, T., Takeuchi, Y., Takeda, R., 1994. Angiotensin-converting enzyme polymorphism and essential hypertension. Lancet., 343(8889):125.

[8] Morshed, M., Khan, H., Akhteruzzaman, S., 2002. Association between angiotensin I converting enzyme gene polymorphism and hypertension in selected individuals of the Bangladeshi population. J Biochem Mol Biol., 35(3):251254.

[9] Nakano, Y., Oshima, T.,Hiraga, H., Matsuura, H., Kajiyamag, K. M., 1998. DD genotype of the angiotensin I converting enzyme gene is a risk factor for early onset of essential hypertension in Japanese patients. $J$ Lab ClinMed., 131(6):502506.

[10] Randhawa NK, K. A., Matharoo, K., Bhanwer, A.J.S., 2006. Association Study of Angiotensin Converting Enzyme Ins/Del Polymorphism with Hypertension in Punjabi Population. Int J Hum Genet., 6: 317-321.

[11] Rigat, B., 1990. An insertion/deletion polymorphism in the angiotensin I converting enzyme gene accounting for half the variance of serum enzyme levels. Journal of Clinical Investigation., 86(4): p. 1343.

[12] Sameer, A.S., 2010. ACE I/D Polymorphism in Hypertensive Patients of Kashmiri Population. Cardiology Research., 1(1): p. 1-7.

[13] Soubrier, F., 1988. Two putative active centers in human angiotensin I converting enzyme revealed by molecular cloning. Proceedings of the National Academy of Sciences., 85(24): p. 9386. 